\title{
Electrochemical Corrosion Behavior of Ferritic Steels in Molten $(\mathbf{L i}, \mathbf{N a}, \mathbf{K}) \mathbf{F}$
}

\author{
Yanli Wang ${ }^{1, *}$, Huijun $\mathrm{Liu}^{2}$, Chaoliu Zeng ${ }^{2}$, and Weihua $\mathrm{Li}^{1, *}$ \\ ${ }^{1}$ School of Chemistry and Chemical Engineering, Guangxi University, Nanning, 530004, P R China. \\ ${ }^{2}$ Laboratory for Corrosion and Protection, Institute of Metal Research, Chinese Academy of Sciences, \\ 62 Wencui Road, Shenyang 110016, P R China. \\ "E-mail: wyl15104008565@126.com
}

doi: $10.20964 / 2018.02 .14$

Received: 23 October 2017 / Accepted: 2 December 2017 / Published: 28 December 2017

The corrosion of ferritic steels in fluoride salts limits the development of advanced molten salt reactors. In-situ electrochemical measurements for B409M and B439 were performed at $700{ }^{\circ} \mathrm{C}$ in molten $(\mathrm{Li}, \mathrm{Na}, \mathrm{K}) \mathrm{F}$ by potentiodynamic polarization and electrochemical impedance spectroscopy. The experimental results indicate that the current densities for B409M and B439 are approximately 631 and $738 \mu \mathrm{A} \cdot \mathrm{cm}^{-2}$, respectively. The impedance spectra plots for B409M and B439 are both composed of two capacitance loops for the duration of a $100 \mathrm{~h}$ experimental test. Cr-depleted corrosion layers are formed on the surface of B409M and B439 through fluoridation processes. And the corrosion mechanism is also discussed.

Keywords: Ferritic steel, Corrosion mechanism, Electrochemical, Molten (Li,Na,K)F.

\section{$\underline{\text { FULL TEXT }}$}

(C) 2018 The Authors. Published by ESG (www.electrochemsci.org). This article is an open access article distributed under the terms and conditions of the Creative Commons Attribution license (http://creativecommons.org/licenses/by/4.0/). 